\title{
Social Studies Education in Indonesia
}

\author{
Warsono \\ Universitas Negeri Surabaya \\ Surabaya, Indonesia \\ warsono@unesa.ac.id
}

\begin{abstract}
In Indonesia, social studies education is inseparable from the establishment of state and nation which is not only to get freedom from colonialism and to proclaim independence, but also to get the citizen be aware of living peacefully together. The awareness as a citizen in a nation needs to be built through education, such as social studies education and civic education. Civic education aims to build awareness as a citizen who understand their rights and obligations along with obeying and upholding laws and regulations. While, social studies education is for building awareness as a parata of a nation consists of various tribes, cultures and religions. Therefore, it requires tolerance towards differences. The implication of this is that social studies education and civic education have been included into the curriculum since elementary school.
\end{abstract}

Keywords— social studies, education

\section{INTRODUCTION}

In Indonesia, social studies cannot be separated from the nation's development [1]. Even though social studies were formally began in around 1964, actually, it had already started since the proclamation of independence. The state founders proclaimed the independence on 17th August 1945, which was built not only based on the country, but also based on nation and character. It can be clearly understood from Ir. Soekarno's statement, who said that what we built were nation-state and nation-character $[2,3]$. The development of the state can be said to have been completed, when Indonesia proclaimed its independence's day on August 17th, 1945 along with the establishment of Pancasila as the base and 1945 Constitution of Indonesia (UUD 1945) as the written basic law on 18 August 1945. In its journey, Indonesia still experiences dynamics because some groups want to establish an Islamic state [4].

The emergence of notion as the substitute basis of the state, the establishment of an Islamic state will need to be related back to Pancasila. An Understanding of the life of the nation, and being a good citizen should continue to be implanted to every generation. This is due to those who were not born during the era of the struggle for independence may have little knowledge and understanding about country and nation. Minimum knowledge will certainly affect their attitude and perspective on the nation and state.

The establishment of the state does not mean that the development of the nation is also completed automatically, it can only be said as the beginning or at least in the process of maturing. An awareness to build the nation began since 1908 with the establishment of Boedi Oetomo, followed by the youth pledge in 1928. Boedi Oetomo's tought which was written in the youth pledge "... acknowledge one nation, that is the nation of Indonesia", still becomes a goal and not yet a reality [5]. This could be why Bung Karno reaffirms that nation-state and nation-character must be built.

Even though Indonesia proclaimed its independence on August 17th 1945, that does not mean everyone has understood how to live in a country as a citizen. At the beginning of the independence, not all citizens understood of what rights and obligations of every citizen which ruled by law in a legislation. Therefore, citizens should be educated how to live in a state organization, thus knowing their rights and obligations, both to the state, government and fellow citizens.

Since 1956, the subjects of citizenship had been incorporated in the school curriculum, which subsequently changed its name to Civics. In 1974 it was renamed the Pancasila moral education, and now back with the name of civic education. This subject is used as an instrument for forming good citizens $[6,7]$. A major objective of civic education is to build a good citizen. One of the indicators of good citizens is abiding the law. The law indeed meant to organize life by giving protection of the rights of each citizen. As a good citizen, they must not only abiding the law, but also capable to participate in national development intelligently [8].

\section{METHOD}

The founding father of Indonesia realized that to build a nation consists of various ethnicities having different culture was not easy. It requires struggle and long process. One of the ways to build a nation-awareness is through education, changing the internal process of psychological, such as knowing, understanding, believing and realizing. Education is the way to transform knowledge, point of view, and attitude [9]. Knowledge of the meaning of a nation needs to be inculcated to all citizens. The way of seeing the existence of ethnic groups and customs of another culture that exists throughout the region of Indonesia should also be changed. At least, the primordial attitudes and viewpoints must be eliminated or reduced, so other ethnic groups could be put in a parallel position and being part of the nation of Indonesia.

Before entering school, children receive education from family, thus their knowledge, attitude and behavior are shaped by the values and norms that is existed in the community. Their Knowledge and values is still limited to local values and 
primordial. Therefore, the transformation process of knowledge, comprehension, enrichment and confidence at schools must be done to equip them for entering wider community, which is Indonesia as a nation [10].

Children must be introduced to various ethnic groups and cultures in Indonesia, in order to know and understand that the nation of Indonesia consists of various ethnic groups and also indigenous culture. They should also realize that the differences should not be disputed, but instead were put together in one container. The unity of these various ethnic groups and cultures are called "Bhinneka Tunggal Ika" [11]. Unification in one nation does not mean eliminating the characteristic of each ethnic groups, but instead, appreciating and respecting the differences.

\section{RESULT AND DISCUSSION}

Younger generation should be educated on living together in a society which respect the values of democracy. They have to not only appreciate the difference, but also uphold the law and ethics in life. This is in line with the primary mission of social studies education i.e. "... to help young people develop the ability to make informed and reasoned decisions for the public good as citizens of a culturally diverse, democratic society in an interdependent world" [12,13].

The mission of social studies education is actually not differ from civic education mission, which is forming a good citizens. However, social studies education has wider aims than civic education, because it developes not only the ability as citizens, but also the ability as citizens of the nation and the community. Citizens concerned with the life of a country that abide the law and execute rights and obligations in accordance with the regulations, including political rights and obligations. Citizens correlated to indigenous peoples and cultures that are owned by the nation (citizens of culturally diverse). Social studies education should be able to build an awareness of cultural diversity with its value because the nation of Indonesia is built of various etnicities and culture. Therefore, the understanding and awareness of the Bhineka Tunggal Ika must be built since childhood [14]. Thus, they can associate with the environment by upholding the prevailing ethics in the society.

The growth of consciousness as a citizen, nation, and society is not easy and instant. Since birth, children are educated in family environment with homogeneous value system. In order to enter a social life, they must be educated at school, so that they understand the wider and the more diverse social realities [15]. This may have different values that of the family values. Moreover, to enter the life of a nation, it requires an education to understand the existence of wider diversity and values [16]. As well as the understanding and awareness as citizens, it also requires education to understand the system of state administration, rights and obligations.

Social studies education as a school subjects is in the elementary and middle school curriculum. This education continues until senior high school but with more specific subject, such as sociology, anthropology, geography, history and others. Social studies education in the elementary school aims to develop students potential in order to be considerate of social problems, have a positive mental attitude towards the social inequality, and resolve any problems that occur in the community skillfully, both that befell him and the society. In the 2006 curriculum, the aims of social studies subject in elementary schools are: 1) to recognize concepts related to community and environment; 2) have basic skills for logical and critical thinking, curiosity, inquiry, problem solving, and skillfull in society; 3) have a commitment and awareness of social and humanitarian values, and have the ability to communicate, work together and compete in diverse societies on a local, national and global scale [17].

If we observe closely, there is no significant difference between the definition of social learning objectives in elementary and junior high schools, and maybe even in high school. Social studies in elementary and junior high school also have similiar scope, such as: 1) human, place, and environment; 2) time, sustainability, and alteration; 3) social and cultural systems; 4) economic behavior and welfare. Aside from the fact of the age and social enfirontment differences between elementary and junior students. Junior high schoolers tend to have a wider and diverse social environment compared to the elementary school students, as well as the different level of thinking. According to Peaget statement, elementary school students (aged 7-11 years) are included as operational category, because they do not have a good ability in abstraction yet. While junior high school students (age 11-18 years), are included as formal operational category, because they are able to think abstractly and logically, even able to think deductively and inductively and build a hypothesis [18]. Based on these differences, the materials, methods and learning strategies between elementary and junior high school should also be differentiated.

In the 2013 curriculum, social studies in elementary school are integrated into Pancasila and Civic Education and Bahasa $[19,20]$. Meanwhile in junior high school, social studies education stand alone as a integrative subject. Social studies education is intended as an applicative-oriented education. It could also develop the ability of thinking, learning, curiosity, caring and responsible attitude towards the social and natural environment. The purpose of social studies education is emphasized on the knowledge of the nation, the spirit of nationalism, patriotism, and the economic activities in the unitary State of Republic of Indonesia.

Curriculum 2013 has the characteristics of scientific and integrative approach that insist teachers to be creative, and have the ability to think scientifically. Teachers must be able to guide students' thinking processes coherently and consistently by providing stimulus in the form of critical and directed questions [21]. Therefore, teachers must have the competence to ask a clear, deep, and coherent question. Teachers should encourage student in the process of learning, presenting the creative material, choosing the innovative method and using the suitable media, so that the learning process can run effectively and fun.

In a view of teaching materials on social studies, there is a difference between elementary and junior high, especially from scope material. The subject material in elementary is limited to identify theirself, family and neighborhood 
community. Whereas the social studies material in junior high school covers wider social interaction, outside the family environment and covers the community with its values and norms. If the methods and strategies used by teachers remain the same between elementary and junior grade, then the results will not be optimal. This is because the ability to understand (abstract) of elementary school students is different from junior high school. In fact, most teachers are less creative in developing learning strategies and packing materials which encourage high-level thinking.

In relation to social studies education in Indonesia, I conducted research on graduate students in UNESA, who are social studies teachers from various regions and received scholarships from the Ministry of Education and Culture to continue their master's degree. The data were drawn from the Lesson Plans (RPP), whether using the 2013 curriculum or School Based Curriculum (KTSP), and interviews to find out their arguments in preparing the RPP. This is based on the assumption that RPP is an academic script, which describes the maker's logic (argument). At least in the RPP, there are components that can be studied in terms of logic (coherency and consistency), namely: Basic Competence (KD) to be achieved; Indicators of achievement; Material to be delivered; Methods and media used; As well as evaluation tools compiled. All these components must be interlinked, coherent and consistent.

The logical connection between these components can be explained that $\mathrm{KD}$ is a competence that must be mastered by learners. Teachers must understand the $\mathrm{KD}$ in order to create indicators of achievement, develop materials, and choose methods and media that can help them to achieve the basic competence (KD). Besides, the teacher must also develop evaluation tools that can measure the achievement of the competence of learners. Evaluation tools can be developed from indicators that have been created, by adding a question word [22]. From the description, the key word to achieve KD is the teacher's understanding of any KD substance, both from the aspects of knowledge (concepts and theories), cognitive and affective which associated with KD.

From the data obtained, there are fundamental problems in social studies teachers. First, they failed to understand the substance of KD. They pay less attention to the cognitive, knowledge, and affective aspects. This failure causes them difficulties to develop learning materials which is relevant to the defined KD. As a result, the evaluation tools that they compile are also not capable to measure the expected competencies. Secondly, teachers tend to be in hegemony of the policies of their superiors (especially the education authorities). Education authorities give less space for teachers to innovate and caused teachers less daring to develop their creativity and innovation, such as developing the suitable learning materials and choosing the alternative method.

In curriculum 2013, basic competencies in social studies education require a more thorough understanding. If we observe closely, all of the KD 3.1 in class I, VIII and IX are about the spatial aspects and connectivity between space and time, the changes and sustainability of human life (economic, social, culture, educational and political). Among these similiaties, there are also differences, such as in class VII. It is on a regional scope, but class VIII discusses national scope. While in class IX, cognitive level is no longer targeting students to understand, but to targeting the level of spatialconnectivity aspects between space and time in order to manifest the unity of the archipelago.

Similiar case also accure in KD 3.2; KD 3.3 and KD 3.4. All of the KD 3.2 in class VII; VIII and IX speak about the change of society from the aspects of geography, economics, culture, education, and politics yet, it differs in its cognitive level. For example, in class VII the cognitive level is understanding, while in class VII, the cognitive level is describing, and in class IX at the review level. The other differences is the time dimension, where in class VII is discussing the period of pre-script (pra-aksara), Hindhu Budha, and Islam. In class VII speaks about the colonial period and the growth of the national anthem. While in class IX discuss the period of movement until the beginning of reform.

In KD 3.3, and 3.4 there are also similarities between classes VII, VIII, and IX. KD 3.3 discusses social institutions, while KD 3.4 discusses human interaction with the natural environment. However, the difference lies in students' thinking ability and scope. The ability of teachers to understand and map the substance of $\mathrm{KD}$ is crucial to the success of social sciences education. According to my research, almost $95 \%$ of teachers are not able to understand and map the substance of KD. These failures cause teachers unable to develop learning materials.

There is no consistency and coherency between KD, indicators, learning materials, and evaluation tools from RPP made by the teachers. This is because teachers tend to be pragmatic by adopting the existing RPP without criticizing the substance. Teachers also did not dare to develop their own RPP or edit the existing RPP. Moreover, assessment point which done by the principal or Education Authorities in evaluating teacher's RPP is only based on the existing RPP. Thus, different RPP will be considered wrong, even though the existing RPP often do not have consistency and coherency between its components.

Success in achieving the goals of social studies education requires critical, creative, and innovative teachers, who also understand the various theories of social science and deliver students to achieve the established KD with effective learning material [23]. In fact, critical thinking of most teachers is still low, as a consequent, their ability to think creative and innovative is also low.

The failure of teachers in making the RPP, resulted the class less successful in aiming its goals. One of the indicators is the radical attitude and behavior of our students. The emergence of radicalism among students indicates that Pancasila and Civic Education and social studies education still have not given optimal results. The results of a survey conducted by the Maarif Institute in December 2015 indicates that the attitude of radicalism among students have reached a worrisome condition, although the percentage is still low. 


\section{CONCLUSION}

Social studies education requires a dialogical and dialectical strategy to build awareness in community life and nationhood. This awareness must be based on a belief which refers to the comprehensive knowledge. Social studies education is intended to build awareness of the importance of living together peacefully with the social and natural environment. Therefore, teachers of social studies education must master the various theories in social science, and have the ability to think critically, creatively, and comprehension, so able to change knowledge, ways of thinking, and foster awareness of life of society and nation to their students.

Social studies education is not just a transformation of knowledge, but rather how to develop a critical, analytical, and comprehensive way of thinking, so teachers able to produce student's belief and awareness that Bhineka Tunggal Ika, NKRI, Pancasila and the 1945 Constitution are the "right" choises in this society, nation, and state.

\section{REFERENCES}

D. Kingsbury, The politics of Indonesia: Oxford University Press, 2002.

[2] H. K. Wibisono, S. AP, and M. AP, "Indonesia's Foreign Politics 1955-1965: Between Decolonisation and Beacon Politics," International Journal of Indonesian Studies, vol. 1, pp. 3-4, 2015.

[3] W. A. Redfern, Sukarno's guided democracy and the takeovers of foreign companies in Indonesia in the 1960s: University of Michigan, 2010

[4] M. Van Bruinessen, "Genealogies of Islamic radicalism in postSuharto Indonesia," South East Asia Research, vol. 10, pp. 117 $154,2002$.

[5] H. M. Tarver, A. Mirkovic, and A. O. Mendoza, "ABC-CLIO eBook Collection."

[6] R. L. Dudley and A. R. Gitelson, "Political literacy, civic education, and civic engagement: a return to political socialization?," Applied Developmental Science, vol. 6, pp. 175182, 2002.

[7] J. Torney-Purta, R. Lehmann, H. Oswald, and W. Schulz, Citizenship and education in twenty-eight countries: Civic knowledge and engagement at age fourteen: ERIC, 2001

[8] J. Gastil, "Adult civic education through the National Issues Forums: Developing democratic habits and dispositions through public deliberation," Adult education quarterly, vol. 54, pp. 308328, 2004.

[9] P. Nilsson, "Teaching for understanding: The complex nature of pedagogical content knowledge in pre-service education," International Journal of Science Education, vol. 30, pp. 12811299,2008

[10] M. Scardamalia and C. Bereiter, "Schools as knowledge-building organizations," Today's children, tomorrow's society: The developmental health and wealth of nations, pp. 274-289, 1999.

[11] Y. Prastiwi, "Transmitting Local Cultural Knowledge through English as Foreign Language (EFL) Learning as a Means of Fostering "Unity in Diversity"," Academic Journal of Interdisciplinary Studies, vol. 2, p. 507, 2013.

[12] H. Barr, "Defining social studies," Teachers and curriculum, vol. $1,2017$.

[13] J. D. Hoge, "Character education, citizenship education, and the social studies," The social studies, vol. 93, pp. 103-108, 2002.

[14] W. Damon and D. Hart, Self-understanding in childhood and adolescence: CUP Archive, 1991.

[15] E. R. Auerbach, "Toward a social-contextual approach to family literacy," Harvard Educational Review, vol. 59, pp. 165-182, 1989.

[16] J. A. Banks, "Diversity, group identity, and citizenship education in a global age," Educational researcher, vol. 37, pp. 129-139, 2008.

[17] A. Yusuf, "Kesiapan Sekolah dalam Mengimplementasikan Kurikulum Tingkat Satuan Pendidikan (KTSP)," Lembaran Ilmu Kependidikan, vol. 36, 2007.

[18] J. B. Dusek, J. F. Flaherty, and J. P. Hill, "The development of the self-concept during the adolescent years," Monographs of the Society for Research in Child Development, pp. 1-67, 1981.

[19] C. R. Prihantoro, "The perspective of curriculum in Indonesia on environmental education," International Journal of Research Studies in Education, vol. 4, pp. 77-83, 2015.

[20] D. Kusumaningsih, "Indonesian Text Role as Draft Science in Curriculum 2013: Assessment Introduction Text Structure Strategies In Indonesian Book," Asian Journal of Sciences and Humanities, vol. 2, pp. 1-4, 2013

[21] S. C. Choy and P. K. Cheah, "Teacher perceptions of critical thinking among students and its influence on higher education," International Journal of teaching and learning in Higher Education, vol. 20, pp. 198-206, 2009

[22] G. F. Madaus and T. Kellaghan, "Curriculum evaluation and assessment," Handbook of research on curriculum, pp. 119-154 1992.

[23] R. G. Tharp and R. Gallimore, Rousing minds to life: Teaching, learning, and schooling in social context: Cambridge University Press, 1991 